\title{
Factors Associated with Calf Mortality under Field Condition in Saurashtra Region of Gujarat, India
}

\author{
T.K. Patbandha ${ }^{1}$, D.D. Garg', B.R. Maharana ${ }^{2}$, M.R. Chavda ${ }^{1}$, \\ Rupal Pathak ${ }^{3}$ and V.V. Gamit ${ }^{1}$ \\ ${ }^{1}$ Polytechnic in Animal Husbandry, College of Veterinary Science and A. H., Junagadh \\ Agricultural University, Junagadh-362 001, Gujarat, India \\ ${ }^{2}$ Referral Veterinary Diagnostic and Extension Centre, Lala Lajpat Rai University of Veterinary \\ and Animal Science, Uchani, Karnal-132 001, Haryana, India \\ ${ }^{3}$ College of Veterinary Science and A. H., Sarkanda, Bilaspur-495 001, \\ Chhattisgarh Kamdhenu Vishwavidyalaya, India \\ *Corresponding author
}

\begin{tabular}{|c|c|}
\hline & 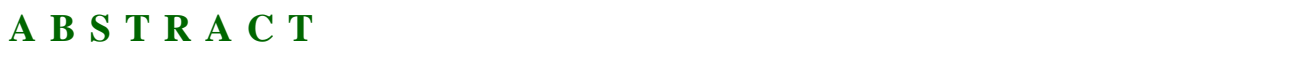 \\
\hline & \multirow{6}{*}{$\begin{array}{l}\text { Present study investigated factors associated with calf mortality under field condition. } \\
\text { Information regarding calf management and calf mortality were collected from } 160 \\
\text { respondents of Saurashtra region of Gujarat. Majority of respondents were literate } \\
(78.75 \%) \text {. Farmers mostly allowed suckling of calves for colostrum within } 1 \text { to } 2 \text { hours } \\
\text { after birth }(72.5 \%) \text { and offered } 1-2 \text { liters colostrum per day }(61.25 \%) \text {. They allowed calves } \\
\text { for suckling before and after milking }(73.75 \%) \text { but } 26.25 \% \text { allowed one teat completely for } \\
\text { suckling. Very few farmers practiced weaning }(15.63 \%) \text { whereas, } 60.63 \% \text { farmers offered } \\
\text { calf starter. Farmers mostly preferred to house the calves in one side of shed }(91.88 \%) \text {. } \\
\text { About } 43.75 \% \text { farmers dewormed advanced pregnant dams, but majority of farmers } \\
\text { dewormed healthy calves from birth to one month }(79.37 \%) \text {. Very few farmers practiced } \\
\text { cutting of navel cord followed by disinfection }(17.50 \%) \text {. In most instances, farmers called } \\
\text { veterinarians or paravets for treatment of diseased calves }(83.75 \%) \text {. Incidence of calf } \\
\text { mortality was observed to be } 16.03 \% \text { which differed significantly with herd size } \\
(P<0.001) \text {. Calf mortality was significantly higher }(25 \%) \text { in small size herd followed by } \\
15.09 \% \text { in medium and } 6.51 \% \text { in large size herd }(P<0.001) \text {. Correlation study revealed that } \\
\text { sooner the calves were fed with colostrum after birth then their survival rate increased } \\
\text { significantly }(r=0.249, P=0.001) \text {. Deworming of pregnant dam significantly reduced calf } \\
\text { mortality }(r=-0.167, P=0.034) \text {. There was a trend of increase in calf survival as soon as } \\
\text { they were dewormed after birth }(r=0.153, P=0.053) \text {. Taken together it may be concluded } \\
\text { that majority of farmers were aware about better calf managemental practices, and certain } \\
\text { calf management practices were significantly associated with calf mortality under field } \\
\text { condition in Saurashtra region of Gujarat. }\end{array}$} \\
\hline Keywords & \\
\hline $\begin{array}{l}\text { alf management, } \\
\text { alf mortality, } \\
\text { cidence. }\end{array}$ & \\
\hline Article Info & \\
\hline $\begin{array}{l}\text { Accepted: } \\
29 \text { June } 2017 \\
\text { Available Online: } \\
\text { 10 July } 2017\end{array}$ & \\
\hline & \\
\hline
\end{tabular}

\section{Introduction}

India produced 155.5 million tonnes milk during 2015-16, continued to be largest milk producing nation in the world. Gujarat shared about $7.9 \%\left(3^{\text {rd }}\right.$ position $)$ of total milk produced in India during the same period with per capita availability above the national average (Anonymous, 2017). Though 18\% households have dairying is the main source 
of livelihood (Anonymous, 2016) in Gujarat. Calf mortality acts as one of the major obstacles and $20 \%$ calf mortality reduces net profit to approximately $40 \%$ (Singh et al., 2009). Incidences of calf mortality varies from 2 to $20 \%$ in exotic dairy breeds under temperate climate (Radostits et al., 2000). However, in India calf mortality ranges from 12.5 to $30 \%$ (Singh et al., 2009), even it may be as high as $81 \%$ (Tiwari et al., 2007).

Though calf mortality occurs due to multifactorial causes, management of pregnant dam, calving management as well as care and management of the newborn calf significantly affect calf mortality (Lorenz et al., 2011). Previous studies revealed a wide variation of the scientific calf management practices adopted by dairy farmers in Gujarat (Patel et al., 2014; Sabapara et al., 2015; Chaudhary et al., 2016; Divekar et al., 2016; Sabapara, 2016). Although several authors reported care and management of dairy calf in Gujarat particularly north, south, middle and eastern part, the information at Saurashtra region is scanty. Incidences of calf mortality and correlation of managemental factors with calf mortality are also scanty.

Further, Jaffrabadi buffalo and Gir cattle are the main dairy animals in Saurashtra region of Gujarat which significantly contributed to the milk pail of the state. Hence, present experiment was designed to study the calf management practices followed by the dairy farmers in Saurashtra region of Gujarat and their association with calf mortality under field condition.

\section{Materials and Methods}

The study was conducted at Saurashtra region of Gujarat located at western part of India during 2013-2014 where climate is semi-arid to dry sub-humid (rain fall $537-850 \mathrm{~mm}$ per annum and ambient temperature minimum $10^{\circ} \mathrm{C}$ during January to maximum $45^{\circ} \mathrm{C}$ during May and June). Information related to calf management practices (feeding, housing and health management) including education level of respondents, herd size, number of calf born and died during last one year were collected using a pre-tested structured interview schedule.

Four districts were selected purposefully, 2 talukas from each district, 2 villages from each taluka and 10 respondents from each village with a total of 160 respondents. Out of 160 respondents, 96 had small size herd (1-5 adult animals), 48 had medium size herd (610 adult animals) and 16 had large size herd (more than 10 adult animals) with a total of 964 adult cattle and buffaloes. The data collected were compiled, tabulated for frequency and converted into percentage to draw inferences. Incidence of calf mortality was calculated as per the following standard method.

$$
\begin{aligned}
\text { Calf mortality }(\%) & \text { Number of calves died } \\
\text { Total number of calves at risk } & \text {------ } \times 100
\end{aligned}
$$

Incidence of calf mortality among different herd size (small, medium and large) was compared by chi-square test and significance difference between two groups was compared by proportionate z-test. Parameters associated with calf mortality were assigned some score based on degree of effect on calf health and survival (such as higher educational qualification of respondents, good management and health care practices were assigned higher score) for the correlation study. Correlation between parameters related to calf management (independent variables) with calf mortality (dependent variable) was also analysed by Pearson's correlation coefficient. Statistical analysis were conducted using Sigma plot 11 software package (Systat Software, Inc., California, USA) and considered as significant when $P \leq 0.05$. 


\section{Results and Discussion}

\section{Feeding and housing management practices}

Education level of respondents and general calf management practices opted by farmers of Saurashtra region of Gujarat are presented in table 1. Majority of respondents involved in dairy husbandry practices were literate (78.75\%). In a similar line, others also reported involvement of literate farmers (6394\% literate respondents) in dairy farming in middle-east and south Gujarat (Raval and Chandawat, 2011; Patel et al., 2014; Sabapara, 2014). Association of literate farmers in dairy husbandry practices indicate that farmers may follow improved animal husbandry practices which are essential for reducing calf mortality. Higher participation of literate farmers with dairy husbandry in the study area might be attributed to well established dairy-cooperative system and adequate extension activities.

In general, though farmers allowed the calves to suckle colostrum, the duration from birth to time of suckling was not consistent. New born calves were allowed for suckling colostrum within 1 to 2 hours after birth $(72.5 \%)$ and offered about 1-2 liters of colostrum per day $(61.25 \%)$, whereas, less number of farmers allowed suckling of calf after release of placenta $(7.5 \%)$. The results are more or less similar with the reports by others observed in southern and middle-eastern part of Gujarat (Sabapara et al., 2015; Divekar et al., 2016). Contrary to our result, in another study, calves were fed colostrum after release of placenta in south Gujarat (60\%, Sabapara, 2016). Further, Chaudhary et al., (2016) also reported that majority of farmers allowed suckling of calf for colostrum after release of placenta (91.67\%) and whatever amount of colostrum available was suckled by the calves $(95.83 \%)$ in northern Gujarat. Farmers in the study area due to more literacy may be more aware about disease resistance property of colostrum; hence majority of them allowed suckling of calves for colostrum as soon as possible after birth. Farmers mostly allowed calves for suckling milk before and after milking $(73.75 \%)$ but remaining $26.25 \%$ farmers leave one teat for milk suckling. However, no specific age up to which milk has to be fed to calf was fixed by farmers. Contrary to our result, others reported that majority of respondent allow one teat for suckling calves at South Gujarat (Sabapara et al., 2015; Sabapara, 2016).

Very few farmers practiced weaning of calves $(15.63 \%)$ and about $60.63 \%$ respondents offered calf starter for better growth. On the other hand, Sabapara et al., (2015) reported that majority of farmer weaned calves after 3 months $(58.67 \%)$ and few farmers offered calf starter $(2.67 \%)$ at south Gujarat. Moreover in our study, farmers mostly practiced natural weaning of calves might be attributed to lack of awareness regarding advantages of weaning practices. In a similar line, Chaudhary et al., (2016) cited that after dryoff of mother all the calves were naturally weaned. Moreover, about $8 \%$ farmers offered grains along with oil seed cakes but majority of respondents (83\%) offered leftover food (Chaudhary et al., 2016). Calves were offered roughage after $2-3$ months of age $(67.51 \%$ respondents) which is similar to Sabapara et al., (2015). Farmers preferred to house calves in the same place where dams were kept towards one side $(91.88 \%)$ may be due to smaller herd size as observed in this study. In consonance with Sabapara et al., (2015), in less instances winter bedding was provided to calves $(11.25 \%)$.

\section{Health management practices}

Calf health management practices followed by the dairy farmers in Saurashtra region of 
Gujarat are presented in table 2. About $43.75 \%$ farmers dewormed their advanced pregnant animals to prevent transmission of endoparasites particularly ascariasis from mother to calves just after birth through colostrum. However, majority of farmers dewormed healthy calves during birth to one month $(79.37 \%)$ but less number of farmers dewormed after onset of infection (20.63\%). Contrary to our result, Sabapara et al., (2015) reported that 48.67 and $40.67 \%$ farmers, respectively use anthelmintics regularly and occasionally for deworming at south Gujarat. Moreover, in another study at south-eastern region of Gujarat, majority of respondents $(61.3 \%)$ did not deworm calves (Patel et al., 2014). When there was any difficulty during calving process, $44.38 \%$ farmers took assistance of veterinarians or paravets whosoever available. Very few farmers practiced cutting and disinfecting navel cord of calves (17.50\%) which is similar to the previous reports i.e. 0-4.17\% (Sabapara et al., 2015; Patel et al., 2014; Chaudhary et al., 2016). Farmers mostly called vets or paravets for treatment of diseased calves $(83.75 \%)$ which is similar to Patel et al., (2014).

\section{Factors associated with calf mortality}

Incidence of calf mortality under field condition was observed to be on an average $16.03 \%(84 / 524)$, which varied significantly with herd size (Table 3, $\mathrm{P}<0.001$ ). Incidence of calf mortality was significantly higher in smaller herds $(25.0 \%)$, followed by medium $(15.09 \%)$ and lower incidence in herd with larger size $(6.51 \%)$. Calf mortality observed under field condition in this study is comparable with the previous reports (9.8$32.9 \%$ ) in India (Singh et al., 2009; Mane et al., 2010; Kalam et al., 2016). However, higher calf mortality (81.09 and $79.97 \%$, respectively) has been reported by Tiwari et al., (2007) and Sreedhar and Sreenivas (2015) in India. Further, calf mortality in tropical climate has been reported to be as high as $50 \%$ (Moran, 2011). Mortality of calf could be reduced by proper management practices like adequate colostrum feeding soon after birth, proper hygiene and housing to reduce disease transfer and proper feeding protocols to enhance rumen growth etc (Lorenz et al., 2011; Moran, 2011). Although, several authors reported increased calf mortality with increase in herd size in commercial dairy farms in India as well as outside India (Tiwari et al., 2007; Sreedhar and Sreenivas, 2015; Seppä-Lassila et al., 2016), we observed more survival of calf in larger herds (>10 to 23) compared to smaller ( 1 to 5 animals) or medium (6-10 animals) herds. Further, correlation study revealed non-significant association of herd size with calf mortality, though it showed a decreasing trend in incidence of calf mortality with increase in herd size $(r=-0.139, P<0.079$, Table 4). Higher calf mortality in larger herd may be associated with larger group size of calves resulted lesser time spend per calf or more opportunity for pathogen exchange, while improved management and care in small herd may improve survival rate (Zucali et al., 2013, Seppä-Lassila et al., 2016). Further, defining herd size may be one of the reasons of variation of results among different studies, as in our study large herd includes 11 to 23 adult bovines whereas, in previous studies (Zucali et al., 2013, Seppä-Lassila et al., 2016) more than 100 adult dairy animals. In our study, farmers with medium to larger herd size were member of dairy co-operative system which is well established in Gujarat. Farmers may be more aware about good calf management practices due to their association with co-operative system; on the other hand farmers keeping few animals were less associated with co-operative system and may be keeping animals to produce milk for their home consumption. Additionally, though dairy co-operative system is well organised in Gujarat, Patel et al., (2014) reported non- 
association of $25 \%$ farmers to any organization.

Correlation of different managemental factors and their association with calf mortality is presented in tables 4 and 5. Sooner the calves were fed with colostrum after birth, their survival rate increased significantly $(r=$ $0.249, P=0.001)$. In a similar line, Zucali et al., (2013) also observed significant association of colostrum feeding time and calf mortality in dairy calves. Risk of calf mortality increases drastically with delay in colostrum feeding (Zucali et al., 2013) due to inadequate passive transfer of immunoglobulin through the gut which may subsequently suppresses disease resistance capacity of calves (Godden, 2008).

Table.1 Education level of respondents and general calf management $(n=160)$

\begin{tabular}{|c|c|c|c|}
\hline Sr. no. & & Parameters & Percent \\
\hline \multirow[t]{2}{*}{1} & \multirow[t]{2}{*}{ Education level } & Literate & $78.75(126)$ \\
\hline & & Illiterate & $21.25(34)$ \\
\hline \multirow[t]{3}{*}{2} & \multirow{3}{*}{$\begin{array}{l}\text { Time of colostrum } \\
\text { feeding }\end{array}$} & Within 1-2 hrs after birth & $72.50(116)$ \\
\hline & & Within 2-3 hrs after birth & $20.00(32)$ \\
\hline & & After release of placenta & $7.50(12)$ \\
\hline \multirow[t]{3}{*}{3} & \multirow{3}{*}{$\begin{array}{l}\text { Quantity of colostrum } \\
\text { fed to calf }\end{array}$} & $1 / 10^{\text {th }}$ of body weight/ day & $30.63(49)$ \\
\hline & & 1-2 litres/ day & $61.25(98)$ \\
\hline & & 2-3 litres/ day & $8.13(13)$ \\
\hline \multirow[t]{2}{*}{4} & \multirow[t]{2}{*}{ Milk feeding } & Leave one teat full & $26.25(42)$ \\
\hline & & Before and after milking & $73.75(118)$ \\
\hline \multirow[t]{4}{*}{5} & \multirow[t]{4}{*}{ Milk feeding age } & Age of one month & $14.38(23)$ \\
\hline & & Age of two month & $25.63(41)$ \\
\hline & & Age of three month & $25.63(41)$ \\
\hline & & Above three month age & $34.38(55)$ \\
\hline \multirow[t]{2}{*}{6} & \multirow[t]{2}{*}{ Housing facility } & Separate house & $8.13(13)$ \\
\hline & & Same place with dam in one side & $91.87(147)$ \\
\hline \multirow[t]{2}{*}{7} & \multirow{2}{*}{$\begin{array}{l}\text { Bedding facilities for } \\
\text { calf }\end{array}$} & Yes & $11.25(18)$ \\
\hline & & No & $88.75(142)$ \\
\hline \multirow[t]{2}{*}{8} & \multirow[t]{2}{*}{ Weaning } & Yes & $15.63(25)$ \\
\hline & & No & $84.38(135)$ \\
\hline \multirow[t]{2}{*}{9} & \multirow[t]{2}{*}{ Calf starter feeding } & Yes & $60.63(97)$ \\
\hline & & No & $39.38(63)$ \\
\hline \multirow[t]{3}{*}{10} & \multirow[t]{3}{*}{ Feeding roughage } & One month & $32.5(52)$ \\
\hline & & Two months & $5.63(9)$ \\
\hline & & Three months or above & $61.88(99)$ \\
\hline
\end{tabular}

Values within parenthesis indicates frequency 
Table.2 Calf health management practices $(n=160)$

\begin{tabular}{|c|c|c|c|}
\hline Sr. no. & \multicolumn{2}{|c|}{ Parameters } & Percent \\
\hline \multirow[t]{2}{*}{1} & \multirow[t]{2}{*}{ Deworming of dam } & Yes & $43.75(70)$ \\
\hline & & No & $56.25(90)$ \\
\hline \multirow[t]{2}{*}{2} & \multirow[t]{2}{*}{ Vet assistance } & Yes & $44.38(71)$ \\
\hline & & No & $55.63(89)$ \\
\hline \multirow[t]{3}{*}{3} & \multirow{3}{*}{$\begin{array}{l}\text { Cutting and disinfecting } \\
\text { navel cord }\end{array}$} & Cutting and disinfecting & $17.50(28)$ \\
\hline & & Only cutting but no disinfection & $38.75(62)$ \\
\hline & & No cutting and no disinfection & $43.75(70)$ \\
\hline \multirow[t]{4}{*}{4} & \multirow[t]{4}{*}{ Deworming time } & Within one week of birth & $42.50(68)$ \\
\hline & & Within two weeks of birth & $6.25(10)$ \\
\hline & & Within one month of birth & $30.63(49)$ \\
\hline & & After infection & $20.63(33)$ \\
\hline \multirow[t]{3}{*}{5} & \multirow[t]{3}{*}{ Treatment } & Call vets or paravets & $83.75(134)$ \\
\hline & & Use local medicines & $15.00(24)$ \\
\hline & & Never call vets or paravets & $1.25(2)$ \\
\hline
\end{tabular}

Values within parenthesis indicates frequency

Table.3 Calf mortality percent under field condition

\begin{tabular}{|l|c|c|c|}
\hline Herd size & Total calf born & No. of calf died & Mortality (\%) \\
\hline 10 bovines & 169 & 11 & $6.51^{\mathrm{a}}$ \\
\hline $6-10$ bovines & 159 & 24 & $15.09^{\mathrm{b}}$ \\
\hline$>1-5$ bovines & 196 & 49 & $25.00^{\mathrm{c}}$ \\
\hline Total & 524 & 84 & 16.03 \\
\hline \multicolumn{3}{|c|}{} & $23.20, \mathrm{df}=2, \mathrm{P}<0.001$ \\
\hline $\begin{array}{l}\text { Superscripts are put based on } \mathrm{z} \text {-test: } \mathrm{z} \text { value between large and medium }=2.338 ; \quad P=0.019 ; \mathrm{z} \text { value } \\
\text { between large and medium }=2.164 ; \quad P=0.03 ; \mathrm{z} \text { value between large and small }=4.611 ; \quad P=<0.001\end{array}$ \\
\hline
\end{tabular}

Table.4 Correlation of education, herd size, and feeding, housing and general management with calf mortality $(\mathrm{n}=160)$

\begin{tabular}{|l|l|c|c|}
\hline Sr. no. & Parameters & Correlation coefficient $(\mathbf{r})$ & P value \\
\hline 1 & Education & 0.107 & 0.179 \\
\hline 2 & Herd size & -0.139 & 0.079 \\
\hline 3 & No. of calf born & -0.094 & 0.238 \\
\hline 4 & Time of colostrum feeding & 0.249 & 0.001 \\
\hline 5 & Quantity of colostrum feeding & 0.163 & 0.425 \\
\hline 6 & Milk feeding & -0.039 & 0.618 \\
\hline 7 & Milk feeding age & 0.013 & 0.870 \\
\hline 8 & Housing facility & -0.070 & 0.376 \\
\hline 9 & Bedding facilities & 0.030 & 0.701 \\
\hline 10 & Weaning & 0.026 & 0.742 \\
\hline 11 & Calf starter feeding & 0.071 & 0.370 \\
\hline 12 & Feeding roughage & 0.125 & 0.114 \\
\hline
\end{tabular}


Table.5 Correlation of health management with calf mortality $(\mathrm{n}=160)$

\begin{tabular}{|c|l|c|c|}
\hline S. No. & Parameters & Correlation coefficient (r) & P value \\
\hline 1 & Deworming of dam & -0.167 & 0.034 \\
\hline 2 & Vet assistance & 0.089 & 0.262 \\
\hline 3 & Cutting-Disinfection & -0.087 & 0.276 \\
\hline 4 & Deworming time & 0.153 & 0.053 \\
\hline 5 & Treatment & -0.021 & 0.796 \\
\hline
\end{tabular}

Deworming has also been considered as one of the factors associated with calf mortality (Wynn et al., 2009) and same being observed in our study. Deworming of dam at the last stage of pregnancy significantly reduced calf mortality $(r=-0.167, P=0.034)$. Further, there was an increasing trend in calf survival as soon as they were dewormed after birth $(r=$ $0.153, P=0.053)$.

Deworming in dam during last trimester prevents transfer of parasites from mother to calf through colostrum as well as milk that happens just after birth. Parasitic infection leads to weakness and dehydration which may enhances calf mortality (Van Der Steen et al., 2014). Though, direct correlation of deworming and calf mortality has not been reported in literature, information regarding effect of deworming on reduction of calf mortality is available.

Srikitjakarn et al., (1987) reported that deworming of calves under village conditions reduced mortality rate of calf along with morbidity from 32 to 10 percent. Recently, Pal et al., (2016) observed 79-85 percent reduction in calf mortality under field condition when deworming practiced from 12 weeks after birth. Uttam et al., (2015) and Islam et al., (2016) also reported that calf as well as older cattle mortality reduced significantly due to deworming as compared to those did not deworm. Thus deworming of pregnant dam and calf at an early age may enhance health and welfare of dairy calves.
The results of the present study indicated that majority of farmers were aware about better calf managemental practices. Incidence of calf mortality decreased with increase in herd size. Calf survival rate increased with reduction in duration from birth to colostrum feeding. Deworming of pregnant dam as well as deworming of calves as soon as possible after birth was associated with reduction of calf mortality.

\section{Acknowledgement}

The authors are thankful to the respondents who provided valuable informations for the study. The Principal and Dean, Veterinary College, Junagadh is highly thankful for providing all research facilities.

\section{References}

Anonymous 2016. National Dairy Development Board Annual Report, 2015-2016, Anand, Gujarat.

Anonymous. 2017. Bulletin of animal husbandry and dairying statistics, 201516. Directorate of Animal Husbandry, Krishibhavan, Gandhinagar, Gujarat.

Chaudhary, D.M., Sheikh, A.S., Patel, S.J., Patel, N.R., Patel, J.H., Chaudhari, S.S. and Parmar, V.N. 2016. Alternate dairy management practices of new born animals followed by dairy farmers during drought in Patan district of Gujarat state, India. Int. J. Agri. Sci., 8(12): 1163-1168. 
Divekar, B.S., Trivedi, M.M. and Dhami, A.J. 2016. Adoption of improved animal husbandry practices by dairy farmers of Kheda district in Gujarat. Int. J. Sci. Environ. Technol., 5(6): 4268-4276.

Godden, S. 2008. Colostrum management for dairy calves. Vet. Clin. N. Am. Food Anim. Pract., 24: 19-39.

Islam, M.R., Sarder, M.J.U., Hossain, K.M.M., Islam, M.H. and Uddin, J. 2016. Effect of age, sex, area and management practices on cattle mortality in Rajshahi division, Bangladesh. J. Adv. Vet. Anim. Res., 3(1): 13-17.

Kalam, R., Tagore, J. and Shankar, O.E. 2016. An evaluation of calf mortality outline in Gir cattle. Glob. J. Anim. Sci. Livest. Prod. Anim. Breed., 5(5): 364368.

Lorenz, I., Mee, J.F., Early, B. and More, S.J. 2011. Calf health from birth to weaning. I. General aspects of disease prevention. Irish Vet J., 64:10.

Mane, M.U., Kulkarni, A.N., Adangale, S.B., Deshmmukh, A.R. and Patil, R.M. 2010. Studies on mortality pattern in buffalo calves. Asian J. Anim. Sci., 5(1): $1-4$.

Moran, J.B. 2011. Factors affecting high mortality rates of dairy replacement calves and heifers in the tropics and strategies for their reduction. AsianAust. J. Anim. Sci., 24 (9): 1318-1328.

Pal, S.S., Sharma, I. and Fareeda, 2016. Clinical importance of scheduled deworming in buffalo calves. Intas Polivet, 17 (1):85-87.

Patel, N.B., Kavad, S.D. and Rao, T.K.S. 2014. Eco-friendly livestock management practices followed by tribal households of Narmada valley region of India. J. Appl. Natural Sci., 6(2): 512-518.

Radostitis, O.M., Gay C.C., Blood, D.C. and Hinchcliff, K.W. 2000. Veterinary
Medicine- A textbook of the diseases of cattle, sheep, pigs, goats and horses. $9^{\text {th }}$ Ed. W. B. Saunders, Philadelphia, USA. pp. 117.

Raval, R.J. and Chandawat, M.S. 2011. Extent of knowledge of improved animal husbandry practices and socioeconomical characteristics of dairy farmers of district Kheda, Gujarat. Int. J. Farm Sci., 1(2): 129-137.

Sabapara, G.P. 2014. Study on dairy husbandry practices in Surat district of south Gujarat. Navsari Agricultural University, Navsari, Gujarat.

Sabapara, G.P. 2016. Feeding management practices of dairy animals in coastal areas of Navsari district of India. Livest. Res. Int., 4(2): 88-93.

Sabapara, G.P., Fulsoundar, A.B. and Kharadi, V.B. 2015. Survey of calf rearing practices followed at rural dairy farms in Surat district. J. Anim. Res., 5(2): 257-261.

Seppä-Lassila, L., Sarjokari, K., Hovinen, M., Soveri, T. and Norring, M. 2016. Management factors associated with mortality of dairy calves in Finland: A cross sectional study. The Vet. J., 216: 164-167.

Singh, D.D., Kumar, M., Choudhary, P.K. and Singh, H.N. 2009. Neonatal calf mortality - An overview. Intas Polivet, 10(11): 165-169.

Sreedhar, S. and Sreenivas, D. 2015. A study on calf mortality and managemental practices in commercial dairy farms. Livest. Res. Int., 3(4): 94-98.

Srikitjakarn, L., Löhr, K.F., Leidl, K. and Hörchner, F. 1987. Metaphylactic deworming program for buffalo calves (Bubalis bubalis) in North-East Thailand. Trop Med Parasitol., 38(3): 191-193.

Tiwari, R., Sharma, M. C. and S. P. Singh. 2007. Buffalo calf health care in commercial dairy farms: a field study in 
Uttar Pradesh (India). Livest. Res. Rural Develop., 19 (3). http://www.lrrd.org/ lrrd19/3/tiwa19038.htm

Uttam, S., Singh, B., Chaudhary, J. K., Bassan, S., Kumar, S. and Gupta, N. 2015. Analysis of morbidity and mortality rate in bovine under village conditions of Uttar Pradesh. The Bioscan, 10(2): 585-591.

Van Der Steen, L., Pardon, B., Sarre, C., Valgaeren, B., Van Hende, D., Vlaminck, L., and Deprez, P. 2014. Intestinal obstruction by Toxocara vitolorum in a calf. Vlaams Diergeneeskundig Tijdschrift, 83(6):
299-305.

Wynn, P.C., Warriach, H. M., Morgan, A., McGill, D.M., Hanif, S., Sarwar, M., Iqbal, A., Sheehy, P.A. and Bush, R.D. 2009. Perinatal nutrition of the calf and its consequences for lifelong productivity. Asian-Aust. J. Anim. Sci., 22: 756-764.

Zucali, M., Bava, L., Tamburini, A., Guerci, M. and Sandrucci, A. 2013. Management risk factors for calf mortality in intensive Italian dairy farms. Itaalian J. Anim. Sci., 12(e26): 162-166.

\section{How to cite this article:}

Patbandha, T.K., D.D. Garg, B.R. Maharana, M.R. Chavda, Rupal Pathak and Gamit, V.V. 2017. Factors Associated with Calf Mortality under Field Condition in Saurashtra Region of Gujarat. Int.J.Curr.Microbiol.App.Sci. 6(7): 4184-4192. doi: https://doi.org/10.20546/ijcmas.2017.607.433 